\title{
The use of Heterosis and Selection Index for Improving some Important Characteristics of Sweet Melon (Cucumis melo L.)
}

\author{
Bayoumy, A. M; Mona. M, Yousry ${ }^{\star *}$; A. K, Hatem ${ }^{*}$; A.M, El-Gamal** \\ "Horticulture Research Institute, Agriculture Research Center, Egypt \\ ** Plant Production Department, Faculty of Agriculture (Saba Basha) Alex. University
}

\begin{abstract}
A breeding program was carried out at Sabahya horticultural research station, Alexandria, Egypt, during the period fringe in the autumn season 2011 till the late summer season 2013. The first part of the study aimed to measure the magnitude of development after two cycles of selfing with selection using selection index method, for two locally lines produced (lin 1 orange flesh and line 2 Sandafa), selfing with selection technique was done in the autumn season of 2011 and the summer season of 2012, and the evaluation of the two selection generations was carried out in early and late summer seasons of 2013. The second part of the study aimed to produce all possible crosses (a complete diallel) between five locally produced lines (with a high degree of homogeneity to be considered approximately pure lines). Crossing among the five lines (Line 1 Kuz-El-Asal, Line $2_{\text {Charantais, Line }} 3_{\text {green flesh }}$, Line $4_{\text {Matruh }}$ and Line $5_{\text {primal }}$ ) was done in the autumn season of 2011 , and the hybrids were evaluated in the summer seasons of 2012 and 2013. Selection index of five important characters had a big role in increased the mean values for these traits. Range values declared that the homogeneity became more within individual for most of traits in second selection generation and check variety compared with original population. Most important significant positive correlation relationships were detected among average fruit number / plant and total yield / plant, net weight with each of the flesh thickness, placenta hardness and netting, flesh thickness with each of the placenta hardness and netting, placenta hardness and netting. In conclusion it could be reported that the hybrids and check variety (Ananas Monanasa) scored the highest values in most characters under studies. Heterosis values were significant and positive over mid-parent and better parents in most crosses for all characters under studies, and most of dominance degrees had appeared.
\end{abstract}

Keywords: Cucumis melo, mass selection, selection index, correlation coefficient and heterosis.

\section{INTRODUCTION}

Melon (Cucumis melo L.) is an, economically, important cross pollinated vegetable species of the family Cucurbitaceae (Claude, 2001). Melon is available all the year-round but the main picking season is June through August. The strategy for breeding $\mathrm{F} 1$ hybrids is to develop parental lines through self-pollination and selection (Robinson and Decker Walter, 1999). Twenty years ago depression, in the important quality traits of sweet melon was noticed to be pronounced, especially in sweetness trait; therefore, total production and cultivated area of sweet melon decreased, compared with cantaloupe cultivars. Accordingly appropriate breeding programs as mass selection with selfing pollination appeared to be useful in improvement of important quality traits in melon (Abd-El-Salam and Marie, 2002). In plant and animal breeding, the best individuals are those selected for the next breeding cycle on the basis of observed phenotypic values for several traits in each candidate individuals. The point is to choose candidate individuals with high genotypic value (s) for various traits. Also selection index (SI) help to select the best individuals which are not directly observed (Jesus et al., 2006). The utilization of hybrid vigor in the breeding of various crops has a great practical importance. It is very important to increase melon yield per unit area as well as the importance of improving the fruit traits (Hatem et al., 2009). 
The current investigation was measured the magnitude of development in quality traits after two cycles of selection generations (using selection index method) from two local lines of melon, and to determine the extent of heterosis, to produce improved locally hybrids.

\section{MATERIALS AND METHODS}

The present investigation was carried out in the three successive years 2011, 2012 and 2013 and included two separate experiments; in the green house and in the open field at Sabahya horticulture research station, Alex, Egypt.

\section{1- Selfing and selection experiment}

This experiment was conducted to study some genetic parameters related to the improvement progress of the melon in breeding program.

\subsection{Plant materials}

- Line 1 Orange flesh; this genotype was selected for orange flesh as a result in the sixth inbreeding generation. of the cross between " Charantaise cultivar (orange flesh) and a land race from Matroh governorate (green flesh).

- Line 2 sandafa: A selected line from Sandafa cultivar (a local cultivar, grown in Upper Egypt, Beni Suif governorate) through selfing and selection for twelve generations).

- Shahd El-Doki a local improved cultivar; introduced by Vegetables Research Department, Horticulture Research Institute, to be used as a standard (check) cultivar.

1.2. Original population (S0) (fifty seeds) of the two parental lines were seeds planted in a green house on the end of August 2011 in foam trays (84 eyes) and transplanted, after one month, on ridges $80 \mathrm{~cm}$ wide and $30 \mathrm{~cm}$ between plants. Selfing technique was performed for all plants at the proper tune.

1.3.Ten percent of the fruits of each genotype were selected, according to selection index values, and their seeds were mixed (mass selection) to get the first selected generation (S1), the same practices were done to obtain the second selected generation (S2) in mid - February 2012. The Characters which had a great consideration in selection included; netting degree, placenta hardness, flesh thickness; net weight and T.S.S.

1.4. Original populations and selection generations (S0, S1 and S2) and Shahd Eldoki (as a check cultivar) were sown in evaluation experiments, in early summer season (in the first of March 2013) and late summer season (in the first of June 2013) to test the achieved progress in the selected traits in a factorial experiment with two factors (genotypes and seasons) in a randomized complete blocks design (RCBD) with three replicates. Each replicate contained 16 rows (where 4 rows were allocated for each of the genotypes S0, S1, S2 and Shahd El-Doki. Each rows was $5 \mathrm{~m}$ long and $130 \mathrm{~cm}$ width, and the hills were thinned out to one plant each with $35 \mathrm{~cm}$ apart at the age of three weeks.

\section{Recorded data}

Normal agriculture practices used for commercial sweet melon production were practiced as used in the area. Data were recorded on 5 random plants per plot as follows:- 
1- Vegetative measurements

- Plant height $(\mathrm{cm})$ : measured from soil surface to the terminal buds of the main stem.

- Branches number: Number of branches at the end of fruit picking.

2- Yield and its components

- Average fruit number/plants.

- Average fruit weight $(\mathrm{kg})$

- Total yield/plant(kg)

3- Fruit characteristics

- Net weight\%: According Mohamed et al (2011) by the following equation:

[(Fruit weight - Placenta weight) / Fruit weight] *100

- Flesh thickness\%: A ratio between flesh thickness and fruit diameter

- Placenta hardness: was rating from 1to10, 1 denoted the juicy placenta tissues and 10 is the hard placenta.

- Netting degree: was rating from 1 to 10, 1 denoted the extreme smooth fruit skin and 10 the heavily rough fruit.

- Total soluble solids (TSS)\%: Determined using the Zeiss hand refractometer.

- Fruit moisture content: Determined by weighting $100 \mathrm{gm}$ of fruit flesh then chopped and dried at $70 \mathrm{c}^{\circ}$ for 5 days until constant weight.

\section{Hybridization experiment}

This experiment was carried out to study the heterosis over mid-and better-parents for several interested characters on developed melon hybrids

2.1. Plant materials (five parental lines and a check cultivar)

- Line 1 Kuz-El-asal; was originated as a result of planting Kuz El-asal (a local cultivar) grown in Assut governorate and selfed for 20 successive generations.

- Line 2 Charantais; Charantaise (European cultivar) a pure line.

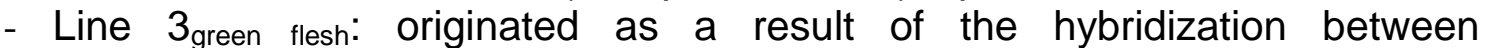
Charantaise and one of the landraces, cultivated in Matruh governorate, F1 plants were individually selfed for six generations, then only one line was selected and selfed for successive fourteen generations until arrived to homogeneity.

- Line $4_{\text {Matrun: }}$ was originated after applying the selfing technique on local landraces from Matruh governorate for twenty generations and arrived to homogeneity.

- Line 5 primal: originated from the primal F1 hybrid, by selfing program for twenty generations, till the selected individual line arrived to homogeneity.

- Ananas Monanasa (a commercial cultivar) was used as a check cultivar.

2.2. Parental genotypes were planted in a green house on the end of August 2011 in foam trays (84 eyes) and transplanted, after one month, on ridges 80 $\mathrm{cm}$ wide and at $30 \mathrm{~cm}$ between plants. Crossing technique was performed, a day before anthesis among the five parents in the two direction.

2.3. The tested 5 parents, 10 hybrids, 10 reciprocals and Ananas Monanasa (26 genotypes) were sown in two experiments for evaluation, during the two successive summer seasons of 2012 and 2013, on the first of March. The experimental design used was a randomized complete blocks design (RCBD) with three replicates. Each replicate contained 52 rows, 2 rows for each genotype. The rows were $5 \mathrm{~m}$ long and $130 \mathrm{~cm}$ wide, the hills were thinned out 
to one plant each, at $35 \mathrm{~cm}$ a part, three weeks later. Recorded data in the second experiment included vegetative measurements, yield and its components and total soluble solids (TSS) as mentioned in the first experiment.

All used parental lines in this study were provided by "The Project of development of main vegetable crops" Horticulture Research Institute, Agriculture Research Center, Ministry of Agriculture, Egypt.

Statistical analysis following:

All the collected data were statistically analyzed according to the

1- Selection indices:_Classical selection index was performed according to Smith (1936) and as illustrated by Singh and Chaudhary (1985):

2- Analysis of variance (ANOVA) was achieved as suggested by Snedecor and Cochran (1980).

3- Coefficient of variation:_Genotypic and phenotypic coefficient of variation were computed according to Burton (1952) by the follow equations:

Genotypic coefficient of variance $(\mathrm{GCV})=(\sqrt{ } \mathrm{VG} / \overline{\mathrm{X}}) * 100$

Phenotypic coefficient of variance $(P C V)=(\sqrt{ } \mathrm{VP} / \mathrm{X}) * 100$

Where; $V G=$ Genotypic variance, $V P=$ Phenotypic variance and $X \overline{=}$ General mean of the trait

4-Heritability; broad sense heritability calculated according to (Hanson et al., 1956) by the following formula: Heritability $=(V G /$ VP $) * 100$

5-Genetic advance (GA): Was calculated according to Johanson et al (1955), by the following formula: $\quad G A=h^{2 *} i * \delta p$

Where; $h^{2}=$ broad sense heritability, $i=$ selection differential $(1.76$ at 10 selection

Intensity) and $\delta p=$ Phenotypic standard deviation.

6- Genetic advance as percent of mean (GAM): for S0, S1 and S2

$$
\mathrm{GAM}=(\mathrm{GA} / \overline{\mathrm{X}}) * 100
$$

Where; $G A=$ Genetic advance and $\bar{X}=$ Mean of population

7- Correlation coefficient: Coefficient of correlation between various pairs of characters (calculated over two evaluated seasons in the second selective generation) was worked out to determine the degree of association among the characters, as shown by Dospekhove (1984), by the following equation.

$$
\mathrm{R}=\sum \mathrm{X}_{1} \mathrm{X}_{2} / \sqrt{ }\left(\sum \mathrm{X}_{1}\right)^{2}\left(\sum \mathrm{X}_{2}\right)^{2}
$$

Where; $\mathrm{X} 1=$ Character number 1 and $\mathrm{X} 2=$ Character number 2

8-Heterosis; heterosis for each cross was calculated according to Bhatt (1971)

- Per cent heterosis over mid parent $(\overline{\mathrm{MP}})=[(\overline{\mathrm{F}} 1-\overline{\mathrm{MP}}) / \overline{\mathrm{MP}}]{ }^{\star} 100$

-Per cent heterosis over better parent $(\mathrm{BP}) \%=[(\overline{\mathrm{F} 1}-\overline{\mathrm{BP}}) / \overline{\mathrm{BP}}]{ }^{*} 100$

-Potence ratio was calculated by the equation, adopted by Peter and Frey

(1966), as follows:

$$
\mathrm{PR}=(\overline{\mathrm{F} 1}-\overline{\mathrm{MP}}) /(\overline{\mathrm{BP}}-\overline{\mathrm{MP}})
$$

Where $; \overline{\mathrm{F}} 1=$ Mean of the $\mathrm{F} 1$ hybrid, $\overline{\mathrm{MP}}=$ Mean of the parents of that particular F1 cross

and $\overline{\mathrm{BP}}=$ Mean of the better parent of that particular cross 


\section{RESULTS AND DISCUSSION}

Regarding the first experiment (Selfing and selection), data in Tables (1) and (2) showed the mean performances of the selected genotypes in the first selection generation and the second selection generation, respectively, of five interested traits used for selection. The individuals "lines" of each population were arranged descendingly in order to calculate select the index value.

Table 1. Mean performances and selection index values of the genotypes were selected to get the first selection generation, of the two melon lines under studies (autumn season of 2011).

\begin{tabular}{ccccccc}
\hline \hline $\begin{array}{c}\text { Genotypes } \\
\text { number }\end{array}$ & $\begin{array}{c}\text { Netting } \\
(1-10)\end{array}$ & $\begin{array}{c}\text { Placenta } \\
\text { hardness } \\
(1-10)\end{array}$ & $\begin{array}{c}\text { Flesh } \\
\text { thickness\% }\end{array}$ & $\begin{array}{c}\text { Net } \\
\text { weight\% }\end{array}$ & TSS & $\begin{array}{c}\text { Selection } \\
\text { index values }\end{array}$ \\
\hline 3 & 8.5 & 6.5 & 56.5 & 92.5 & 12.1 & 367.47 \\
20 & 9.5 & 7.5 & 51.5 & 93.5 & 12.5 & 366.28 \\
30 & 9.5 & 7 & 54.5 & 94 & 9.5 & 366.21 \\
45 & 6.5 & 8 & 57.5 & 94 & 11.1 & 364.45 \\
32 & 8.5 & 8 & 58 & 92.5 & 11.9 & 363.88 \\
\hline \hline & 7 & 7.5 & 54 & 92.615 & 9.5 & 454.38 \\
\hline 4 & 6.5 & 8.5 & 57 & 94.4 & 9.5 & 434.28 \\
20 & 7 & 7 & 56 & 93.5 & 7.6 & 394 \\
42 & 6.5 & 8 & 54 & 93.43 & 7 & 373.33 \\
3 & 6.5 & 7.5 & 52.5 & 92.745 & 7.5 & 348.75 \\
\hline \hline
\end{tabular}

Table 2. Mean performances and selection index values of the genotypes, selected, to get the second selection generation, of the two melon lines under studies (summer season of 2012).

\begin{tabular}{ccccccc}
\hline \hline $\begin{array}{c}\text { Genotypes } \\
\text { number }\end{array}$ & $\begin{array}{c}\text { Netting } \\
(1-10)\end{array}$ & $\begin{array}{c}\text { Placenta } \\
\text { hardness } \\
(1-10)\end{array}$ & $\begin{array}{c}\text { Flesh } \\
\text { thickness\% }\end{array}$ & $\begin{array}{c}\text { Net } \\
\text { weight\% }\end{array}$ & TSS & $\begin{array}{c}\text { Selection } \\
\text { index values }\end{array}$ \\
\hline 17 & 10 & 10 & 59 & 94.5 & 13 & 196.46 \\
14 & 10 & 9.5 & 60.5 & 94 & 12.7 & 187.27 \\
32 & 9 & 8.5 & 61 & 93.5 & 9.1 & 183.21 \\
1 & 10 & 9.5 & 55 & 95.5 & 13.9 & 182.72 \\
26 & 10 & 9 & 57.5 & 94 & 12.6 & 181.23 \\
\hline \hline & 7.5 & 6 & 58.5 & 94.31 & 9 & 119.04 \\
22 & 7 & 8.5 & 56 & 92.865 & 8.5 & 115.05 \\
12 & 6.5 & 7 & 59.5 & 93.735 & 9.5 & 113.93 \\
49 & 6 & 8 & 56.5 & 92.47 & 7.1 & 112.71 \\
8 & 5.5 & 6.5 & 59 & 91.025 & 9 & 112.44 \\
\hline \hline
\end{tabular}

From the previous results it can be concluded that the average values for all characters under selection became higher in the second selection generation than those of first selection generation. Indicating that the mass selection using selection index method are useful in improving all studied characters, upon which selection was practiced. Similar trends as these results were reported by 
Abd-El-Salam and Marie (2002), El-Shimi et al. (2003), on melon, and Antonio (2004), on squash who stated that the self-pollination with selection would be useful in improving of the important quality traits. Mohamed et al. (2011) reported also that the high values of selection index, mean that the studied genotypes had a strong correlation between genetic worth and phenotypic performances.

With respect to the mean performances of selected lines, mean performance, values of vegetative measurements, and yield and its components are shown in Table (3), the data illustrated that plant length and average fruit weight decreased due to inbreeding, reflecting some inbreeding depression in the successive generations. These results seemed to have a general agreement with those found by Antonio (2004), on summer squash, El-Shimi et al. (2003) and Mohamed et al. (2011), on melon, who stated that the noticed reduction in plant length be related to inbreeding depression effects. The check cultivar (shahd El-Doki) scored the highest values for plant length, branches number, average fruit number, average fruit weight and total yield / plant; compared to both lines under investigation. Range values decreased generally in the second selected generation, and in check cultivar (shahd el-doki), of most vegetative measurements and yield components characters. These results agreed with those reported by Mohamed et al. (2011) who stated that the inbreeding program and mass selection made the population to be more homogenous, from generation to another, and reached a certain degree of uniformity, with less amount of variation, due to successive inbreeding e.

Mean performance values of fruit characters are presented in Table (4) reflected observed increases on their magnitudes of the selection of the second generation $S_{2}$, and of the check cultivar (shahd Eldoki), for all studied characters of both studied lines. Ranges values for all fruit characters decreased, in the second generation of the various selection and the check cultivar (shahd el-doki). These results might be due to the effects of inbreeding and selection which lead to increased homogeneity within lines. Moisture content\% also decreased also in the second selected generation as a result of selection for hard placenta and a high netting, which agreed with the results stated by Mohamed et al. (2011) who found a highly significant negative correlation between moisture content\% and each of netting degree and placenta hardness and add that the selection for high netting and hard placenta had a great effect on decreased moisture content. 
Table 3. Mean performances and ranges for original population (S0), selection generations (S1 and S2) and Shahd-El-Doki (a check cultivar) of both lines of melon (Line 1 Orange flesh and Line 2 sandafa), for vegetative characters and yield components, over two seasons of the study (early and late summer seasons of 2013).

\begin{tabular}{|c|c|c|c|c|c|c|c|c|c|c|}
\hline \multirow{4}{*}{ G } & \multicolumn{10}{|c|}{ Line 1 Orange flesh } \\
\hline & \multicolumn{4}{|c|}{ Vegetative measurements } & \multicolumn{6}{|c|}{ Yield and its components } \\
\hline & \multicolumn{2}{|c|}{$\begin{array}{c}\text { Plant } \\
\text { length }(\mathrm{cm})\end{array}$} & \multicolumn{2}{|c|}{$\begin{array}{c}\text { Branches } \\
\text { number }\end{array}$} & \multicolumn{2}{|c|}{$\begin{array}{l}\text { Fruit number } \\
\text { / plant }\end{array}$} & \multicolumn{2}{|c|}{$\begin{array}{c}\text { Average } \\
\text { fruit weight }(\mathrm{kg})\end{array}$} & \multicolumn{2}{|c|}{$\begin{array}{l}\text { Total yield } \\
\text { /plant (kg) }\end{array}$} \\
\hline & Mean & Range & Mean & Range & Mean & Range & Mean & Range & Mean & Range \\
\hline So & $188_{a}$ & $175-210$ & $3.06_{a}$ & $2-4$ & $2.89_{a}$ & $2-4$ & $0.90_{b}$ & $0.63-1.00$ & $2.30_{\mathrm{c}}$ & $1.95-$ \\
\hline S1 & $171_{b}$ & $150-198$ & $3.33_{a}$ & $2-4$ & $3.28_{a}$ & $2.7-4$ & $0.77_{b}$ & $0.63-0.92$ & $2.57_{b}$ & 2.31-3.07 \\
\hline S2 & $162_{b}$ & $149-191$ & $3.56_{a}$ & $3-4$ & $3.33_{a}$ & $3-4$ & $0.77_{\mathrm{b}}$ & 0.67 & $3.13_{c}$ & 1.86 \\
\hline \multirow[t]{2}{*}{ Control } & $188_{b}$ & $185-192$ & $3.33_{a}$ & $3-4$ & $3.03 \mathrm{a}$ & 3-3.2 & $1.26 \mathrm{a}$ & $1.19-1.30$ & $3.68_{a}$ & $3.59-3.72$ \\
\hline & \multicolumn{10}{|c|}{ Line 2 Sandafa } \\
\hline so & $228_{a}$ & 204-254 & $2.33_{b}$ & $2-3$ & $2.83_{a}$ & $2-3$ & $1.22_{a}$ & 1.01 & $3.1_{a}$ & $2.23-4.230$ \\
\hline S1 & $232_{a}^{a}$ & $207-254$ & $2.67_{b}$ & $2-3$ & $2.33_{b}^{a}$ & $2-3$ & $1.19_{a}^{a}$ & 0.84 & $2.27 \mathrm{~b}$ & 1.60 \\
\hline S2 & $214_{a}$ & $191-250$ & $2.67_{b}$ & $2-3$ & $2.97 \mathrm{a}$ & $2.8-3$ & $1.16_{a}$ & $0.9-1.35$ & $3.23_{\mathrm{b}}$ & $1.75-3.59$ \\
\hline Control & $188_{b}$ & 185-192 & $3.33_{a}$ & 3-4 & $3.03_{a}$ & 3-3.2 & $1.26 \mathrm{a}$ & $1.19-1.30$ & $3.68 \mathrm{a}$ & $3.51-3.72$ \\
\hline
\end{tabular}

Means with the same alphabetical litter in the column are not significantly different from each other using Duncan's Multiple Range Test at 5\% probability. G ; genotypes, Control ; Shahd El-Doki (check cultivar).

It could be concluded from both Tables (3) and (4), that the data of mean performances of the five characters used in selection, that the recorded increments, after two cycles of inbreeding and selection; were $1.08 \%$ and $3.19 \%, 3.39 \%$ and $5.26 \%, 22.22 \%$ and $25 \%, 28 \%$ and $29 \%, 10 \%$ and $21 \%$; for net weight, flesh thickness, placenta hardness, netting and TSS; in line 1 orange flesh and line 2 sandafa, respectively; relative to those of their two original populations. These results appeared generally, in agreement with these obtained by Abd-El-Salam and Marie (2002) on Ismaellawy sweet melon, and by Priva et al. (2006) and Mohamed et al. (2011), on melon; who demonstrated that selection cycles possessed differences in flesh color, total soluble solids (TSS), $\beta$-carotene and flesh firmness among the selective generation cycles.

With regard to variability, heritability and genetic advance, data of genotypic and phenotypic variances, genotypic and phenotypic coefficient of variances, heritability and genetic advance values are presented in Table (5). Relatively high values for genotypic variance for plant length, flesh thickness and netting, were noticed among . The data of line 2 sandafa, showed slight differences between GCV and PCV values for the characters, average fruit number / plant, total yield / plant (kg), net weight, placenta hardness, netting, TSS\%, and moisture content; whereas, the differences between GCV and PCV values were larger for the other remained studied characters of the two studied lines suggesting that these characters were more affected by the environmental conditions Rasoul et al. (2014). Similar trends to that of these results were reported by Abd El-Salam and Marie (2002) on melon, who found that the values of $(\mathrm{GCV})$ and $(\mathrm{PCV})$ were nearly equal for fruit diameter and flesh thickness traits. Mohamed et al. (2011) reported that the selection for 
quantitative characters was more effective in the characters which have a narrow range between Genotypic and phenotypic coefficients of variance.

As for heritability percentages in the broad sense, which specifies the proportion of the total variability that is due to genetic variance, were found high in plant length and netting, and moderate value for total yield / plant, flesh thickness and placenta hardness; and low for the remain characters in the line 1 orange flesh. High heritability values in line 2 sandafa were found within the average fruit number / plant, net weight, placenta hardness, netting, TSS, and moisture content \%; moderate for plant length, branches number and total yield / plant. Similar results were reported by El-shimi et al. (2003), Rakhi and Rajamony (2005), and Mohamed et al. (2011), who reported high heritability values for fruit- number and -weight, total yield / plant and total soluble solids. Hatem et al. (1997) reported that the low broad-sense heritability seemed be reflect high effects of the environmental conditions. Genetic advance values for line 1 Orange flesh were in the favorable direction and larger in the second selective generation than in the first one for plant length, average fruit weight and total yield / plant, and identical for moisture content. In line 2 sandafa, genetic advance values were larger in the second selected generation than in the first one for plant length, average fruit weight, total yield / plant, netting, moisture content, and identical for branches number. So, it might be concluded that the characters which possessed high broad sense heritability combined with relatively high ratio for genetic coefficient of variability and high genetic advance, might be rapidly improved through selection. 
Table 4. Mean performances and ranges for original population (S0), selection generations (S1 and S2) and Shahd-El-Doki (a check cultivar) of both lines of melon (Line 1 orange flesh and Line 2 sandafa), for fruit characteristics over two seasons of the study (early and late summer seasons of 2013).

\begin{tabular}{|c|c|c|c|c|c|c|c|c|c|c|c|c|}
\hline \multirow{4}{*}{$\mathrm{G}$} & \multicolumn{12}{|c|}{ Line 1 Orange flesh } \\
\hline & \multicolumn{12}{|c|}{ Fruit characters } \\
\hline & \multicolumn{2}{|c|}{$\begin{array}{c}\text { Net weight } \\
\%\end{array}$} & \multicolumn{2}{|c|}{$\begin{array}{c}\text { Flesh thickness } \\
\%\end{array}$} & \multicolumn{2}{|c|}{$\begin{array}{c}\text { Placenta } \\
\text { hardness } \\
(1-10)\end{array}$} & \multicolumn{2}{|c|}{$\begin{array}{c}\text { Netting } \\
(1-10)\end{array}$} & \multicolumn{2}{|c|}{$\begin{array}{c}\text { TSS } \\
\%\end{array}$} & \multicolumn{2}{|c|}{$\begin{array}{c}\text { Moisture } \\
\text { Content } \\
\%\end{array}$} \\
\hline & Mean & Range & Mean & Range & Mean & Range & Mean & Range & Mean & Range & Mean & Range \\
\hline So & $92_{a}$ & $90-95$ & $57 \mathrm{a}$ & $50-62$ & $7 \mathrm{~b}$ & 6-9 & $7 \mathrm{~b}$ & $5-9$ & $11.70 \mathrm{a}$ & $9.0-14.0$ & $93 b$ & $92-95$ \\
\hline S1 & $93_{a}$ & $92-94$ & $58 \mathrm{a}$ & $53-62$ & $9_{a}$ & $7-10$ & $8 b$ & $7-9$ & $11.60 \mathrm{a}$ & $9.8-14.2$ & $92 b$ & $91-93$ \\
\hline S2 & $93_{a}$ & $92-94$ & $59_{a}$ & $56-62$ & $9 a$ & $7-10$ & $9.7_{\mathrm{a}}$ & $9-10$ & $12.99 a$ & $11-14.6$ & $92 b$ & $91.6-91$ \\
\hline Control & $92_{a}$ & $92-93$ & $60_{\mathrm{a}}$ & $60-61$ & $8 \mathrm{ab}$ & $7-8$ & $8 b$ & $7-8$ & 12.63a & $12.2-12.8$ & $95 a$ & $94-95$ \\
\hline & \multicolumn{12}{|c|}{ Line 2 Sandafa } \\
\hline So & $91_{c}$ & $90-91$ & $54_{b}$ & $45-61$ & $6 \mathrm{~b}$ & $5-8$ & $5 b$ & $4-7$ & $6.13 c$ & $5-7$ & $95 a$ & $93-97$ \\
\hline S1 & $93_{\mathrm{ab}}$ & $91-95$ & $56_{a b}$ & $48-61$ & $7 \mathrm{ab}$ & $6-8$ & $7 \mathrm{a}$ & $6-9$ & $6.97 \mathrm{bc}$ & $5-8$ & $94 a b$ & $93-96$ \\
\hline S2 & $94 a$ & $93-95$ & $57_{\mathrm{ab}}$ & $49-61$ & $8 a$ & $7-9$ & $7 \mathrm{a}$ & $5-8$ & $7.83 b$ & 7-12.8 & $94 b$ & $92-95$ \\
\hline Control & $92_{b}$ & $92-93$ & $60_{a}$ & $60-61$ & $8 a$ & $7-8$ & $8 a$ & $7-8$ & $12.63 a$ & $12.2-12.8$ & $95 a b$ & $94-95$ \\
\hline
\end{tabular}

Means with the same alphabetical litter in the column are not significantly different from each other using Duncan's Multiple Range Test at $5 \%$ probability.

G ; genotypes, Control ; Shahd EIODoki (check cultivar) 
Table 5. Estimated values of studied genetic parameters of 11 characters in line 1 orange flesh and line 2 sandafa of melon (combined analysis of the early and late summer seasons of 2013).

\begin{tabular}{|c|c|c|c|c|c|c|c|c|}
\hline \multicolumn{9}{|c|}{ Line $1_{\text {Orange flesh }}$} \\
\hline \multirow{2}{*}{ Traits } & \multicolumn{2}{|c|}{ Variance } & \multicolumn{2}{|c|}{ Coefficient of variability } & \multirow{2}{*}{$\begin{array}{c}\text { Heritability } \\
\%\end{array}$} & \multirow{2}{*}{$\begin{array}{c}\text { Genetic } \\
\text { Advance } \\
\end{array}$} & \multicolumn{2}{|c|}{ Genetic advance over mean(\%) } \\
\hline & GV & PV & GCV & PCV & & & S1 & $\mathrm{S} 2$ \\
\hline Plant length(cm) & 167.27 & 324.16 & 7.45 & 10.37 & 51.6 & 16.35 & 9.58 & 10.10 \\
\hline Branches number & 0.02 & 0.44 & 4.11 & 20.04 & 4.2 & 0.05 & 1.47 & 1.38 \\
\hline Average Fruit number / & 0.06 & 0.44 & 7.44 & 20.92 & 12.66 & 0.15 & 4.5 & 4.43 \\
\hline Average fruit weight (kg) & 0.003 & 0.02 & 6.4 & 16.39 & 15.26 & 0.036 & 4.63 & 4.66 \\
\hline Total yield / plant (kg) & 0.024 & 0.085 & 6.64 & 12.51 & 28.13 & 0.14 & 5.63 & 6.77 \\
\hline Net weight \% & 0.16 & 2.51 & 0.44 & 1.71 & 6.56 & 0.18 & 0.197 & 0.196 \\
\hline Flesh thickness \% & 1.24 & 3.81 & 1.91 & 3.36 & 32.53 & 1.12 & 1.92 & 1.89 \\
\hline Placenta hardness (1-10) & 0.77 & 2.45 & 10.65 & 19.01 & 31.37 & 0.86 & 9.85 & 9.79 \\
\hline Netting $(1-10)$ & 1.56 & 3.16 & 15.34 & 21.86 & 49.28 & 1.54 & 19.67 & 15.94 \\
\hline TSS\% & 0.55 & 3.38 & 6.11 & 15.22 & 16.12 & 0.52 & 4.5 & 4.02 \\
\hline Moisture content $\%$ & 0.35 & 1.89 & 0.65 & 1.49 & 18.71 & 0.45 & 0.49 & 0.49 \\
\hline \multicolumn{9}{|c|}{ Line 2 Sandafa } \\
\hline Plant length(cm) & 79.78 & 309.27 & 3.98 & 7.83 & 25.8 & 7.98 & 3.45 & 3.73 \\
\hline Branches number & 0.037 & 0.16 & 7.53 & 15.796 & 22.73 & 0.16 & 6.06 & 6.06 \\
\hline Average Fruit number / & 0.1 & 0.23 & 11.66 & 17.59 & 43.97 & 0.37 & 15.82 & 12.44 \\
\hline Average fruit weight $(\mathrm{kg})$ & 0.0004 & 0.044 & 1.67 & 17.62 & 0.90 & 0.003 & 0.279 & 0.288 \\
\hline Total yield / plant (kg) & 0.197 & 0.54 & 17.42 & 28.71 & 36.84 & 0.47 & 20.92 & 21.31 \\
\hline Net weight \% & 2.73 & 4.21 & 1.78 & 2.22 & 64.72 & 2.34 & 2.51 & 2.49 \\
\hline Flesh thickness \% & 2.198 & 18.68 & 2.67 & 7.77 & 11.77 & 0.89 & 1.59 & 1.57 \\
\hline Placenta hardness (1-10) & 0.69 & 1.27 & 11.55 & 15.75 & 53.78 & 1.07 & 14.91 & 13.35 \\
\hline Netting $(1-10)$ & 0.83 & 1.97 & 14.17 & 21.76 & 42.37 & 1.05 & 14.59 & 15.31 \\
\hline TSS\% & 0.69 & 1.35 & 11.89 & 16.63 & 51.18 & 1.05 & 15.00 & 13.34 \\
\hline Moisture content $\%$ & 0.63 & 1.21 & 0.84 & 1.17 & 51.8 & 1.003 & 1.06 & 1.07 \\
\hline
\end{tabular}


Respecting correlation coefficients values, are presented in Table (6). Estimated values were found positive and significant or highly significant for the following pairs of characters as plant length and average fruit weight / plant, branches number and total soluble solids (TSS), average fruit number / plant and total yield / plant, total yield / plant $(\mathrm{kg})$ and total soluble solids, net weight with each of flesh thickness, placenta hardness and netting, and flesh thickness with each of placenta hardness and netting. Negative and significant or highly significant correlation values were found for the pairs of the characters plant length with each of branches number, average fruit number / plant, total yield / plant and TSS\%; branches number and average fruit weight / plant; average fruit number and average fruit weight / plant, average fruit weight / plant with each of total yield / plant and TSS\%; and moisture content with each of net weight, flesh thickness, placenta hardness and netting.

Similar trends, more or less, of these results were shown by Reddy et al. (2007), who found a high positive correlation between total yield / plant and fruit weight, a negative significant correlation between average fruit number and average fruit weight. Feyzian et al. (2009) found a significant negative correlation between average fruit number and average fruit weight. Mohamed et al., (2011) estimated highly positive correlations between net weight (\%) and each of placenta hardness, flesh thickness and total sugars; between placenta hardness and each of flesh thickness and TSS (\%); between netting degree and each of TSS (\%) and total sugars; between TSS and total sugars content; and a highly significant negative correlation was estimated between net weight\% and placenta weight.

Table 6. Correlation coefficients estimates between various pairs among 11 studied traits under of melon(combined analysis of the early and late summer seasons of 2013).

\begin{tabular}{lllllllllll}
\hline \hline Traits & \multicolumn{1}{c}{ PL } & BN & AFN/ & AFW/ & TY/P & NW\% & F TH\% & PH & N & TSS \\
\hline \hline BN & $-0.96^{* *}$ & & & & & & & & & \\
AFN/P & $-0.77^{*}$ & 0.7 & & & & & & & & \\
AFW/P & $0.99^{* *}$ & $-0.96^{* *}$ & $-0.81^{*}$ & & & & & & & \\
TY/P & $-0.86^{* *}$ & 0.87 & $0.89^{* *}$ & $-0.86^{* *}$ & & & & & & \\
NW\% & -0.63 & 0.54 & 0.08 & -0.49 & 0.29 & & & & & \\
F TH & -0.71 & 0.63 & 0.19 & -0.6 & 0.41 & $0.99^{* *}$ & & & & \\
PH & -0.65 & 0.67 & 0.13 & -0.57 & 0.48 & $0.86^{* *}$ & $0.86^{* *}$ & & & \\
N & -0.62 & 0.58 & 0.08 & -0.49 & 0.38 & $0.96^{* *}$ & $0.97^{* *}$ & $0.89^{* *}$ & & \\
TSS & $-0.97^{* *}$ & $0.96^{* *}$ & 0.74 & $-0.98^{* *}$ & $0.81^{*}$ & 0.55 & 0.63 & 0.54 & 0.53 & \\
MC\% & 0.62 & -0.53 & -0.11 & 0.49 & -0.36 & $-0.98^{* *}$ & $-0.98^{\star *}$ & $-0.87^{* *}$ & $-0.98^{* *}$ & -0.51 \\
\hline \hline
\end{tabular}

*, ${ }^{* *}$ Significant at $5 \%$ and $1 \%$ levels of probability, respectively.

$\mathrm{PL}$; $\quad$ plant length $(\mathrm{cm}), \mathrm{BN}$; Branches number, AFN; Average fruit number, AFW; Average fruit weight $(\mathrm{kg})$, TY; Total yield / plant $(\mathrm{kg})$, NW\%; Net weight, F TH\% ; Flesh thickness. PH; Placenta hardness(1-10), N ; Netting degree (1-10), TSS\%; Total soluble solids and MC ; Moisture content\%. 
With respect to Hybridization experiment mean performances of the studied genotypes (5 parents, 10 hybrids, 10 reciprocals and Ananas monanasa, as a check cultivar), of the vegetative measurements, yield and its components and total soluble content (TSS) are presented in Table (7). Values of plant length and branches number were higher in most of hybrids and reciprocals than those of the parents. The highest values of plant length was that of hybrid (L5 $\times$ L3), followed by that of $(L 5 \times L 4)$. The highest value for branches number appeared to be that of $(\mathrm{L} 1 \times \mathrm{L} 5)$, followed by that of $(\mathrm{L} 2 \times \mathrm{L} 3)$. Total yield $(\mathrm{kg})$ values were generally large in magnitude for hybrids and reciprocals than for their parents. Similar results, more or less, were reported by Feyzian et al. (2009). The highest average fruit number of the hybrid (L5 $\times L 3)$ was followed by those of $(L 1 \times L 3),(L 3 \times L 5)$ and $(L 5 \times L 4)$, respectively. The highest genotype in average fruit weight was the parental line (L1) followed by the parental line (L2). The highest total yield was found be that of the hybrid $(\mathrm{L} 2 \times \mathrm{L} 5)$ followed by hybrid $(\mathrm{L} 2 \times \mathrm{L} 4)$. The hybrids gave generally higher values for TSS, than their parental lines. Similar results were reported by Reddy et al. (2007) and Mohamed et al. (2011). The highest genotype as for TSS (\%) was the hybrid $(\mathrm{L} 3 \times \mathrm{L} 2)$, followed by $(\mathrm{L} 2 \times \mathrm{L} 5),(\mathrm{L} 3 \times \mathrm{L} 5)$ and $(\mathrm{L} 5 \times \mathrm{L} 2)$ respectively.

Likewise, heterosis \% over the mid-parental value and the better parent and potence ratio were computed for vegetative measurements, yield and its components and total soluble solids (TSS) are presented in Table (8). The data showed significant positive heterosis over mid-parent and better parents for plant length in all hybrids with the exception of $(L 2 \times L 4),(L 2 \times L 3)$ and $(L 4 \times L 3)$. The high obtained potence ratio values, noticed in most of hybrids were in accordance with the hybrid vigor. These results might be referring to the presence of over dominance towards the high plant length in most of the hybrids. Hybrids (L1 $\times L 5)$, $(\mathrm{L} 2 \times \mathrm{L} 3)$ and $(\mathrm{L} 2 \times \mathrm{L} 4)$ had significant positive heterosis over mid-parents, and hybrid ((L2×L1) had significant positive heterosis over both med-parents and high parent, for the trait high branches number. Similar results, more or less, were obtained by Abd El-Rahman et al. (2011), on melon, who detected over dominance toward high plant length and branches number. Heterosis values for average fruit number / plant were found positive in most of crosses, over midparents and better parent, and significant in $(\mathrm{L} 1 \times \mathrm{L} 2),(\mathrm{L} 5 \times \mathrm{L} 3)$ and $(\mathrm{L} 5 \times \mathrm{L} 4)$ over med-parents and better parent, and in (L1 $\times$ L3), (L3 $\times$ L4), (L3 $\times$ L5) and (L4 $\times$ L2) over mid-parent only. As for, the average fruit weight; the heterosis values were found negative and significant in most of the crosses these results suggested the presence of that the hybrid vigor for high fruit number and low average fruit weight. The same trend was in heterosis values for total yield / plant; which, presented high positive significant values for heterosis in most of the crosses over midparents and better parent. Potence ratios were, in accordance, with the hybrid vigor hypothesis. These results indicated that high total yield is more controlled by average fruit number. A similar result as reported by El- Shimi et al. (2003), which disagreed with that found by Abd-El-Rahman et al. (2011), who reported that the average fruit weight had a great positive effect on total yield.

Heterosis values for TSS (\%) were found significant and positive for hybrid $(\mathrm{L} 1 \times \mathrm{L} 2)$ over med-parents and better parent, and in the crosses $(\mathrm{L} 1 \times \mathrm{L} 5),(\mathrm{L} 2 \times \mathrm{L} 5)$, (L3 $\times \mathrm{L} 5),(\mathrm{L} 2 \times \mathrm{L} 1),(\mathrm{L} 3 \times \mathrm{L} 1),(\mathrm{L} 4 \times \mathrm{L} 1),(\mathrm{L} 3 \times \mathrm{L} 2)$ and $(\mathrm{L} 5 \times \mathrm{L} 2)$ over med-parents. 
Potence ratios appeared to be positive in most of crosses, which pointed out to the presence of hybrid vigor towards the high TSS value in most of hybrids. Partial dominance for high TSS values appeared in the crosses (L1 $\times L 3)$, (L1 $\times L 4)$, (L2 $\times L 4),(L 5 \times L 1)$ and $(L 4 \times L 2)$. Complete dominance for low TSS value seemed to be reflected on the hybrid (L4×L5).

Table 7. Mean performances of the 5 parents, 10 hybrids and 10 reciprocals and Ananas monanasa (a check variety) of the studied characters of melon over the tow summer seasons of 2012 and 2013.

\begin{tabular}{|c|c|c|c|c|c|c|}
\hline \multirow[b]{2}{*}{ G } & \multicolumn{2}{|c|}{$\begin{array}{c}\text { Vegetative } \\
\text { measurements }\end{array}$} & \multicolumn{3}{|c|}{ Yield and its components } & \multirow[b]{2}{*}{ TSS } \\
\hline & $\begin{array}{c}\text { Plant } \\
\text { length }(\mathrm{cm})\end{array}$ & $\begin{array}{c}\text { Branches } \\
\text { number }\end{array}$ & $\begin{array}{c}\text { Average } \\
\text { Fruit } \\
\text { number } \\
\text { / plant } \\
\end{array}$ & $\begin{array}{c}\text { Average } \\
\text { fruit } \\
\text { weight } \\
(\mathrm{kg}) \\
\end{array}$ & $\begin{array}{c}\text { Total } \\
\text { Yield / } \\
\text { plant } \\
(\mathrm{kg}) \\
\end{array}$ & \\
\hline L1 & 164.56 & $2.94_{c d e}$ & $2.67_{\mathrm{e}}$ & $1.565 \mathrm{a}$ & $2.770_{\text {ahiikl }}$ & $11.27_{\mathrm{ik}}$ \\
\hline L2 & $171_{\mathrm{ij}}$ & $3.11_{\mathrm{bcde}}$ & $2.83_{\mathrm{de}}$ & $1.306_{b}$ & $2.784_{\mathrm{ghijkl}}$ & $12.57_{\text {cdefgh }}$ \\
\hline L3 & $215.83_{\text {fghi }}$ & $2.89_{\mathrm{de}}$ & $3.33_{\mathrm{abcde}}$ & $0.941_{\mathrm{fghi}}$ & $2.864_{\mathrm{ghijk}}$ & 13.37 abcde \\
\hline L4 & $183.28_{\mathrm{hij}}$ & $3.17_{\text {bcde }}$ & $3_{\text {cde }}$ & $1.080_{\text {cdef }}$ & $2.242 \mathrm{mn}$ & $11.03_{k}$ \\
\hline L5 & $160.5_{j}$ & 3.39abcde & $3.03_{\text {cde }}$ & $0.861_{\text {ghij }}$ & $2.550 \mathrm{klm}$ & $12.37_{\text {efghi }}$ \\
\hline $\mathrm{L} 1 \times \mathrm{L} 2$ & $252.39_{\text {cdef }}$ & $3.28_{\mathrm{abcde}}$ & $3.5 \mathrm{abcd}$ & $0.826_{\mathrm{hijk}}$ & $2.776_{\mathrm{ghijkl}}$ & $13.47_{\mathrm{abcd}}$ \\
\hline $\mathrm{L} 1 \times \mathrm{L} 3$ & $289.94_{a b c}$ & $3.28_{\mathrm{abcde}}$ & $3.83_{a b}$ & $0.704_{k}$ & $2.687_{\mathrm{hijkl}}$ & $13.13_{\mathrm{abcdef}}$ \\
\hline $\mathrm{L} 1 \times \mathrm{L} 4$ & $249.17_{\text {cdef }}$ & $3.61_{\mathrm{abcd}}$ & $3.17 \mathrm{bcde}$ & $1.133_{\text {cde }}$ & $3.195_{\text {defg }}$ & $11.17_{\mathrm{k}}$ \\
\hline $\mathrm{L} 1 \times \mathrm{L} 5$ & $223.39_{\text {efgh }}$ & $4 a$ & $3.17_{\mathrm{bcde}}$ & $1070_{\text {def }}$ & $3.033_{\text {efghi }}$ & $12.83_{\mathrm{abcdefg}}$ \\
\hline $\mathrm{L} 2 \times \mathrm{L} 3$ & $267.39_{\text {bcde }}$ & $3.72_{a b}$ & $3.17_{\mathrm{bcde}}$ & $0.896_{\text {ghij }}$ & $2.673_{\mathrm{hijkl}}$ & $13.55_{a b c}$ \\
\hline $\mathrm{L} 2 \times \mathrm{L} 4$ & $194.33_{\text {ghij }}$ & $3.78_{a b}$ & 3.33 abcde & $1.217 \mathrm{bc}$ & $3.786_{a b}$ & $12.47_{\text {cdefghi }}$ \\
\hline $\mathrm{L} 2 \times \mathrm{L} 5$ & $248.44_{\text {cdef }}$ & $3.5_{\mathrm{abcde}}$ & $3.33_{\mathrm{abcde}}$ & $0.993_{\text {efg }}$ & $3.800_{\mathrm{ab}}$ & $13.73_{a b}$ \\
\hline $\mathrm{L} 3 \times \mathrm{L} 4$ & $274.17_{\mathrm{abcd}}$ & $3.28_{a b c d e}$ & $3.67 \mathrm{abc}$ & $1.278_{b}$ & $3.981_{\mathrm{a}}$ & $11.43_{\mathrm{ijk}}$ \\
\hline $\mathrm{L} 3 \times \mathrm{L} 5$ & $239.94_{\text {defg }}$ & $3.61_{\mathrm{abcd}}$ & $3.83_{a b}$ & $0.813_{\mathrm{ijk}}$ & $3.008_{\text {fghij }}$ & $13.73_{\mathrm{ab}}$ \\
\hline L4×L5 & $247.83_{\text {cdef }}$ & $3.5_{\mathrm{abcde}}$ & $3.33_{\mathrm{abcde}}$ & $1.119_{\text {cde }}$ & $3.451_{\mathrm{bcde}}$ & $11.03_{\mathrm{k}}$ \\
\hline $\mathrm{L} 2 \times \mathrm{L} 1$ & $257.22_{\text {cdef }}$ & $3.78_{a b}$ & $3.17_{\mathrm{bcde}}$ & $1012_{\text {efg }}$ & $3.177_{\text {defg }}$ & $12.67_{\text {bcdefgh }}$ \\
\hline $\mathrm{L} 3 \times \mathrm{L} 1$ & $238.44_{\text {defg }}$ & $3.28_{\mathrm{abcde}}$ & $3.5_{\mathrm{abcd}}$ & $0.966_{\mathrm{fgh}}$ & $3.481_{\mathrm{bcd}}$ & 13.4 abcde \\
\hline $\mathrm{L} 4 \times \mathrm{L} 1$ & $311.89_{a b}$ & $3.39_{a b c d e}$ & $3.67 \mathrm{abc}$ & $1.003_{\text {efg }}$ & $3.627_{\mathrm{abc}}$ & $12.33_{\text {efghi }}$ \\
\hline $\mathrm{L} 5 \times \mathrm{L} 1$ & $270.67_{\text {abcde }}$ & $3.67 \mathrm{abc}$ & $3.5 \mathrm{abcd}$ & $0.879_{\text {ghij }}$ & $3.103_{\text {defgh }}$ & $12.33_{\text {fghij }}$ \\
\hline $\mathrm{L} 3 \times \mathrm{L} 2$ & $201.33_{\text {ghij }}$ & $3.56_{a b c d e}$ & $3.17_{b c d e}$ & $0.750_{\mathrm{jk}}$ & $2.3677_{I m n}$ & $13.93_{\mathrm{a}}$ \\
\hline $\mathrm{L} 4 \times \mathrm{L} 2$ & 233.28 defg & $3.67 \mathrm{abc}$ & 3.33 abcde & $0.819_{\mathrm{hijk}}$ & $2.585_{\mathrm{jklm}}$ & $12_{\text {ghijk }}$ \\
\hline $\mathrm{L} 5 \times \mathrm{L} 2$ & $271.94_{\mathrm{abcd}}$ & $3.61 \mathrm{abcd}$ & $3.17_{\mathrm{bcde}}$ & $0.797_{\mathrm{ijk}}$ & $2.090_{n}$ & $13.73_{\mathrm{ab}}$ \\
\hline L4×L3 & $195.83_{\mathrm{hij}}$ & $3.61_{\mathrm{abcd}}$ & $2.83_{\mathrm{de}}$ & $0.948_{\text {fghi }}$ & $2.648_{\mathrm{ijk} \mid}$ & $11.23_{\mathrm{jk}}$ \\
\hline L5 $\times$ L3 & $316.33_{a}$ & $2.83_{e}$ & $4 a$ & $0.709_{k}$ & $3.290_{\text {cdef }}$ & $13.55_{a b c}$ \\
\hline$\llcorner 5 \times\llcorner 4$ & $306.33_{a b}$ & $3.67_{\mathrm{abc}}$ & $3.83_{a b}$ & $0.888_{\text {ghij }}$ & $3.499_{\mathrm{bcd}}$ & $11.6_{h i j k}$ \\
\hline Control & $304_{a b}$ & $2.83_{e}$ & $3.17_{b c d e}$ & $1.191_{\mathrm{bcd}}$ & $3.406_{\text {bcdef }}$ & $12.4_{\text {defghi }}$ \\
\hline
\end{tabular}

Means with the same alphabetical litter in the column are not significantly different from each other using Duncan's Multiple Range Test at $5 \%$ probability.

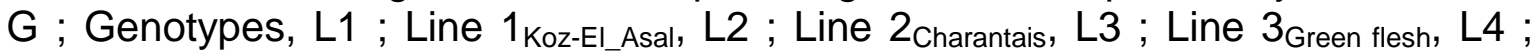
Line $4_{\text {Matroh, }}$ L5 ; Line 5 Primal and Control ; Ananas monanasa (a check cultivar) 
Table 8. Heterosis (ADH\%) over mid and better parents (MP and BP) and potence ratio (PR) for 10 hybrids and their reciprocals of all studied characters of melon in second experiment, over tow summer seasons of 2012 and 2013.

\begin{tabular}{|c|c|c|c|c|c|c|c|c|c|c|c|c|c|c|c|c|c|c|}
\hline \multirow{3}{*}{$\mathrm{G}$} & \multicolumn{6}{|c|}{ Vegetative measurements } & \multicolumn{9}{|c|}{ Yield and its components } & \multirow{2}{*}{\multicolumn{3}{|c|}{ TSS\% }} \\
\hline & \multicolumn{3}{|c|}{$\begin{array}{l}\text { Plant length } \\
(\mathrm{cm})\end{array}$} & \multicolumn{3}{|c|}{$\begin{array}{c}\text { Branches } \\
\text { Number }\end{array}$} & \multicolumn{3}{|c|}{$\begin{array}{l}\text { Average } \\
\text { fruit number / plant }\end{array}$} & \multicolumn{3}{|c|}{$\begin{array}{c}\text { Average } \\
\text { fruit weight }(\mathrm{kg})\end{array}$} & \multicolumn{3}{|c|}{$\begin{array}{c}\text { Total yield / plant } \\
(\mathrm{kg})\end{array}$} & & & \\
\hline & MP & BP & PR & MP & BP & PR & MP & BP & PR & MP & BP & PR & MP & BP & PR & MP & BP & PR \\
\hline $\mathrm{L} 1 \times \mathrm{L} 2$ & $50.43^{* *}$ & $\overline{47.59^{* *}}$ & 26.26 & 8.26 & 5.36 & 3 & $27.27^{\star \star}$ & $23.53^{*}$ & 9 & $-42.42^{* *}$ & $-47.18^{\star *}$ & -4.71 & -0.03 & -0.29 & -0.13 & $\overline{13.01^{* *}}$ & $7.16^{*}$ & 2.38 \\
\hline $\mathrm{L} 1 \times \mathrm{L} 3$ & $52.45^{\star \star}$ & $34.34^{\star *}$ & 3.89 & 12.38 & 11.32 & 13 & $27.78^{\star *}$ & 15 & 2.5 & $-43.81^{\star *}$ & $-55.00^{* *}$ & -1.76 & -4.6 & -6.17 & -2.76 & $6.63^{*}$ & -1.75 & 0.78 \\
\hline $\mathrm{L} 1 \times \mathrm{L} 4$ & $43.27^{\star *}$ & $35.95^{\star *}$ & 8.04 & 18.18 & 14.04 & 5 & 11.26 & 5.56 & 2 & $-14.32^{\star *}$ & $-27.59^{* *}$ & -0.78 & $27.48^{\star \star *}$ & $15.32^{*}$ & 2.61 & 0.15 & -0.89 & 0.14 \\
\hline L1×L5 & $37.45^{\star \star}$ & $35.75^{\star \star}$ & 30.01 & $26.32^{\star \star}$ & 18.03 & 3.75 & 11.11 & 4.39 & 1.73 & $11.74^{\star \star}$ & $-31.58^{\star *}$ & -0.4 & $14.01^{\star \star}$ & $9.49^{\star}$ & 3.39 & $8.6^{\star *}$ & 3.77 & 1.85 \\
\hline $\mathrm{L} 2 \times \mathrm{L} 3$ & $38.45^{\star *}$ & $23.89^{*}$ & 3.29 & $24.07^{*}$ & 19.64 & 6.5 & 2.7 & -5 & 0.33 & -20.27 & & -1.25 & -5.36 & & 79 & 4.49 & 1.37 & 1.46 \\
\hline $\mathrm{L} 2 \times \mathrm{L} 4$ & 9.71 & 6.03 & 2.8 & $20.35^{\star}$ & 19.29 & 23 & 14.29 & 11.11 & 5 & 2 & & 0.21 & $50.65^{\star *}$ & $35.98^{* *}$ & & 5.6 & -0.79 & 0.87 \\
\hline & $49.89^{* *}$ & $45.29^{\star *}$ & 15.75 & 7.69 & 3.28 & 1.8 & 13.64 & 9.89 & 4 & -8.39 & & -0.41 & $42.45^{\star \star}$ & $6^{* *}$ & 9.6 & $16^{*}$ & 9.28 & 12.67 \\
\hline & 37.3 & $27.03^{\star *}$ & 4.58 & 8.26 & 3.51 & 1.8 & & 10 & 3 & $26.47^{\star \star}$ & & 3.86 & & $98^{* *}$ & 4.5 & & $4.46^{\star *}$ & -0.66 \\
\hline & 27.5 & 11.17 & 1.8 & 15.04 & 6.56 & 1.8 & & 15 & 4.33 & -9.76 & & 19 & 11.12 & & $1 . \subseteq$ & $6.74^{\star}$ & 2. & 1.73 \\
\hline <L5 & 44.1 & $35.22^{\star \star}$ & 6.67 & 6.78 & 3.28 & 2 & & 9.89 & 19 & $15.27^{\star *}$ & 3.5 & 1.35 & 44.02 & $31^{* *}$ & 6.8 & $-5.69^{*}$ & $-10.78^{\star *}$ & -1 \\
\hline $\mathrm{L} 2 \times \mathrm{L} 1$ & $53.31^{* *}$ & $50.42^{* *}$ & 27.76 & $24.77^{*}$ & $21.42^{*}$ & 9 & 15.15 & 11.76 & 5 & $-29.47^{* *}$ & $-35.29^{* *}$ & -3.27 & $14.39^{\star *}$ & $14.10^{*}$ & 56.44 & $6.29^{*}$ & 0.79 & 1.15 \\
\hline $\mathrm{L} 3 \times \mathrm{L} 1$ & $25.37^{\star}$ & 10.48 & 1.88 & 12.38 & 11.32 & 13 & $16.67^{*}$ & 5 & 1.5 & $-22.89^{\star \star}$ & $-38.25^{\star *}$ & -0.92 & $23.55^{\star \star}$ & $21.52^{* *}$ & 14.12 & $8.79^{* \star}$ & 0.25 & 1.03 \\
\hline $\mathrm{L} 4 \times \mathrm{L} 1$ & $79.33^{* *}$ & $70.17^{\star *}$ & 14.74 & 10.91 & 7.02 & 3 & $29.41^{\star *}$ & 22.22 & 5 & $-24.15^{\star \star}$ & $-35.89^{\star *}$ & -1.32 & $44.74^{\star \star}$ & $30.84^{\star *}$ & 4.24 & $10.61^{*}$ & 9.47 & 10.14 \\
\hline $\mathrm{L} 5 \times \mathrm{L} 1$ & $66.54^{\star *}$ & $64.48^{* *}$ & 53.33 & 15.79 & 8.19 & 2.25 & $22.81^{\text {** }}$ & 15.38 & 3.55 & $-27.55^{\star}$ & $-43.84^{\star *}$ & -0.95 & $16.64^{\star \star}$ & $12^{*}$ & 4.02 & 3.53 & -1.08 & 0.76 \\
\hline $\mathrm{L} 3 \times \mathrm{L} 2$ & 4.09 & -6.72 & 0.35 & 18.52 & 14.29 & 5 & 2.7 & -5 & 0.33 & $-33.22^{* *}$ & $-42.54^{* *}$ & -2.05 & $-16.17^{*}$ & $-17.37^{*}$ & -11.44 & $7.46^{*}$ & 4.24 & 2.42 \\
\hline $\mathrm{L} 4 \times \mathrm{L} 2$ & $31.69^{\star *}$ & $27.28^{*}$ & 9.14 & 0.81 & 15.79 & 19 & $14.29^{*}$ & 11.11 & 5 & $-31.37^{* *}$ & -37 & -3.31 & 2.87 & -7.15 & 0.27 & 1.69 & -4.51 & 0.26 \\
\hline L5×L2 & $64.07^{\star *}$ & $59.03^{* *}$ & 20.23 & 11.11 & 6.56 & 2.6 & 7.95 & 4.39 & 2.33 & $-26.43^{\star *}$ & $-38.97^{\star *}$ & -1.29 & -21.63 & $-24.93^{\star *}$ & -4.93 & $10.16^{* *}$ & 9.28 & 12.67 \\
\hline$L 4 \times L 3$ & -1.87 & -9.27 & -0.23 & 19.27 & 14.04 & 4.2 & -10.53 & -15 & -2 & -6.18 & -12.2 & -0.89 & 3.74 & -7.53 & 0.31 & $-7.92^{\star}$ & $-15.96^{\star \star}$ & -0.83 \\
\hline L5×L3 & $68.11^{* *}$ & $46.56^{\star *}$ & 4.63 & -9.73 & -16.39 & -1.22 & $25.65^{\star *}$ & $20^{*}$ & 5.44 & -21.35 & & -4.79 & $21.55^{\star \star}$ & $14.88^{\star}$ & 3.72 & 5.31 & 1.37 & 1.37 \\
\hline $\mathrm{L} 5 \times \mathrm{L} 4$ & $78.22^{\star *}$ & $67.14^{* *}$ & 11.8 & 11.86 & 8.19 & 3.5 & $27.07^{\star \star}$ & $26.37^{\star \star}$ & 49 & -8.49 & $-17.77^{\star \star}$ & -0.75 & $46.03^{\star \star}$ & 37.20 & 7.15 & -0.85 & $-6.19^{*}$ & -0.15 \\
\hline
\end{tabular}

*, ** Significant and highly significant at the 0.05 and 0.01 level of probability, respectively.

G ; genotypes, L1 ; Line 1 Koz-El Asal, L2 ; Line 2 Charantais, L3 ; Line 3 Green flesh, L4 ; Line 4 Matroh, L5 ; Line 5 Primal. 


\section{REFERENCES}

Abd-El-Salam, M.M.M and R. Marie. 2002. Genetical studies for improvement of fruit quality and yield of sweet melon (Ismaellawy). J. Agric. Sci. Mansoura. Univ, 27(11):7583-7593.

Abd-El-Rahman, M. E., A. M. El-Gamal; M. A. Mousa; S. Omima. 2011. Genetically studies on some important characters on melon (Cucumis melo, L. ) A Thesis submitted, Alex. Univ. Egypt.

Antonio, I. I. C. 2004. Depression by inbreeding after four successive selfpollination Squash generation. Sci. Agric. (Piracicaba. Braz)., 61(2):224227.

Bhatt, G. M. 1971. Heterosis performance and combining ability in a diallel cross among spring wheat (Triticum sativum L. ) Australian J. Agric. Res. 22: 329-368.

Burton, G.W. 1952. Quantitative inheritance in grass. In proceeding of the six the international grassland congress .Pennsylvania, U.S.A: 217-283.

Claude, H.C. 2001. Generation means analysis of plant architecture and fruit yield in melon (Cucumis melo L. ) Costarica department of agriculture, Agri. Res. Service (USDA, AR.S). 86-122.

Dospekhove, B.A. 1984. Field experimental, statistical procedures. Mir Publishers: 349.

El-Shimi, A.Z.A, S.A. Mohamedein and A.H. El-Fouly. 2003. Inheritance of some economic traits in melon (Cucumis melo, L.). J. Agric. Sci. Mansoura. Univ. 28(6):4907-4918.

Feyzian, E., H. Dehghani; A. M. Rezai and M. Jalali. 2009. Correlation and sequential path model for some yield-related traits in melon (Cucumis melo, L.) J. Agric. Sci. Technol. 11: 341-353.

Hanson, C. H., D. S. Robinson and R. E. Comestock. 1956. Biometrical studies of yield in segregating populations of Korean Lespedezas. Agro. J., 48: 268-272.

Hatem, A.K., M.I. Ragab and H.A. Abd-El-Meggeed. 1997. Genetical studies of some fruit characteristics in melon (C.melo, L.) Menofiya. J. Agric. Res. 22(3):889-904.

Hatem, M.K., A.A. Manal and R.A. Shabrawy 2009. Hetrosis for yield components and some characters in melon (Cucumis melo, L.). J. Agric. Kafr Elsheikh. Univ. 35(1):293-307.

Jesùs. C.R., C. Josè, S.C. Jaime, C.G. Fernando and V.S. Amalio 2006. Aselection index method based on Eigenanalysis. J. of Natural Resource and life. 46:1711-1721.

Johanson, H. W., H. F. Robinson, and R. E. Comstock. 1955. Estimates of genetic and environmental variability in soybean. Agro. J. 47: 314-318.

Mohamed, A. M., A M. El-Gamal, M. A. Zeiton and M. A. Mousa. 2011. Breeding for improving fruit quality in sweet melon (Cucumis melo, L.) and increasing its storability in tow local cultivars. A thesis submitted, Alex. Univ. Egypt

Peter, F. G. and K. J. Fery 1966. Genotypic correlation, dominance and heritability of qualitative characters in oat. Crop. Sci., 6: 259-262.

Priva, W. O, J. L. Mosca, H. A. C. Filgueiras, C. R. M. Lima, J. B. R. Mesquta, F . W. A. Freitas and R. F. Caitano. 2006. Improved quality and 
nutritional value of melon. XXV11 International Horticultural congress. (1HC) 2006: II International Symposium on Plant Genetics Resources of Horticultural crops. 1SHS ACTA Horticultural 760.

Rakhi, R and L. Rajamony 2005. Variability heritability and genetic advance in landrace of Culinary Melon (Cucumis Melo, L.). J. Trop. Agric., 43(1-2):7982.

Rasoul, M., D. Hamid and K. Ghasem 2014. Genetic analysis of yield components, early maturity and total soluble solids in Cantalupe (Cucumis melo L. subsb. Melo Var Cantalupensis Naudin) Arastram Makalesi / Res. Articl (original paper). 24(1): 79-86.

Reddy, A.N.K., A. D.. Munish, T. K. Behera and A. K. Sureja. 2007. Correlation and path analysis for yield and biochemical characters in snap melon: Cucumis melo var. momordica. Sabrao journal of breeding and genetics. 39(1) 65-72.

Robinson, R.W. and D. S. Decker-Walters. 1999. Cucurbits. Cambridge: CAB International, 1999. 226p.

Singh, R. K. and B. D. Choudhary. 1985. Biometrical methods in quanititative Genetic analysis. Kalyani. New Delhi, 110-002. PP. 287-293.

Smith, H.F. 1936. Adiscriminat function for plant selection. Ann. Eugenics., 7:240250.

Sendecor, G.H and W.C. Cochran 1980. Statistical methods seventh edition. lowa Stat. Univ. Press. Ames.

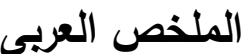

إستخدام قوة الهجين ودليل الانتخاب لتحسين بعض الصفات الهامة فى الشمام

"أحمد محسن بيومى محمد, " "نفى محمد يسرى جابر , "أحمد قطب قطب حاتم "“أحمد محمود عبد

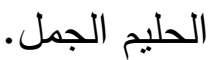

"معهد بحوث البساتين - مركز البحوث الزراعية - مصر

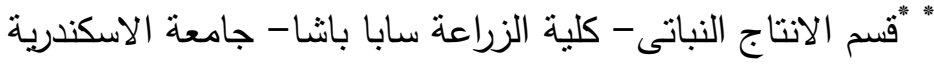

من خلال برنامج تربية بدأ بمحطة بحوث البساتين بالصبحية بالاسكندرية فى الموسم الخريفى لعام 2011 وانتهى فى في

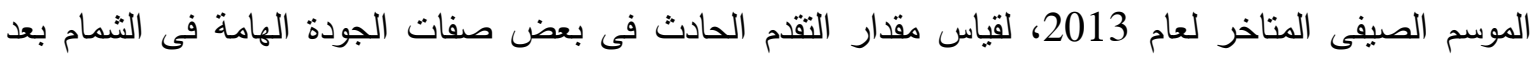

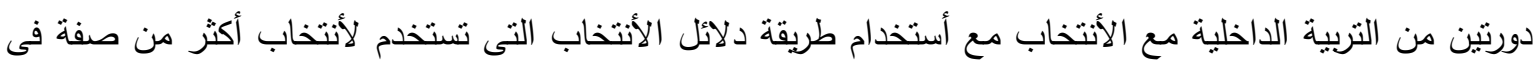
نفس الوقت، وشملت صفات الوزن الصافى \% ر سمك اللحم, تماسك المشيمة, درجة الثبكية, والمواد الصلبة الذائبة

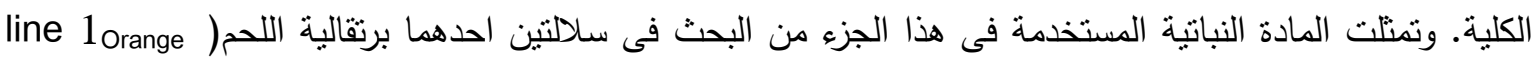
(flesh 
السلالاتان لم تصلا بعد الى درجة عالية من التجانس. وبدأت الدورة الاولى من الانتخاب فى الموسم الخريفى لعام

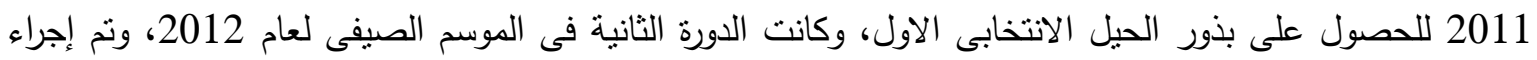

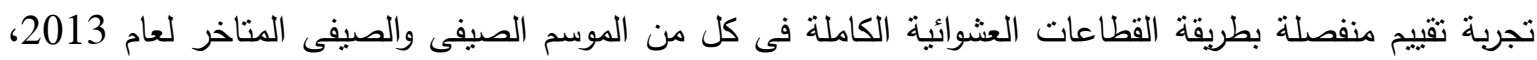

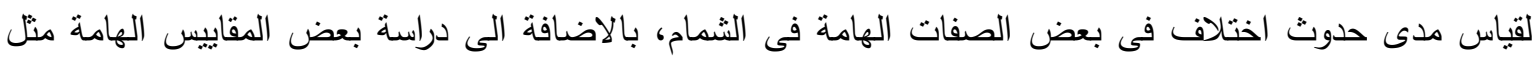

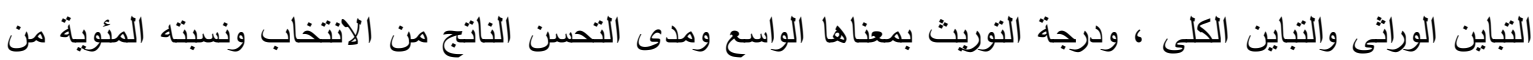
المتوسط العام \%.وأما الجزء الثانى من البحث فتمت إجراء كل التهجينات المدكنة بين بعض السلايلات المستتبطة

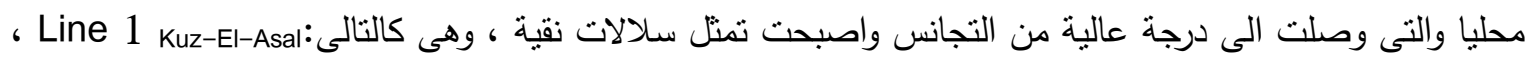

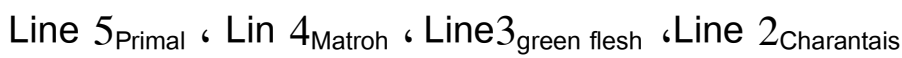

أهم النتائج المتحصل عليها: كان لطريقة دلائل الانتخاب التى طبقت على خمس من صفات الجودة الهامة فى الثمام، وهى الوزن

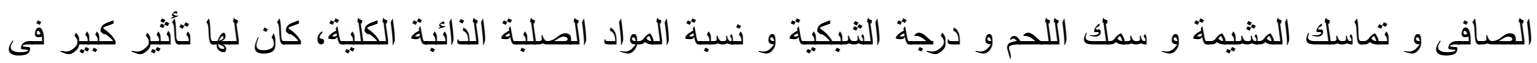

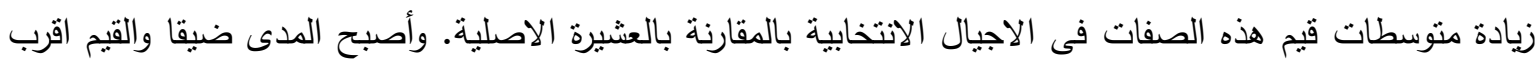

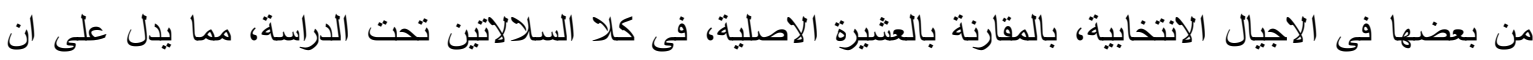

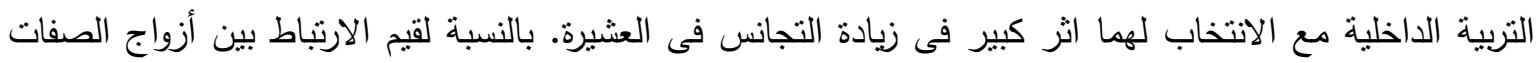

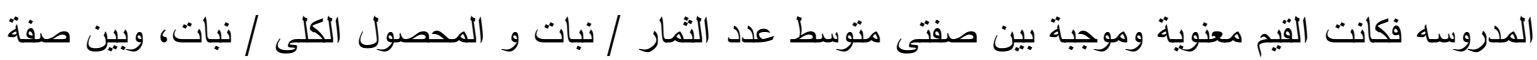
الوزن الصافى وكل من صفات سمك اللحم وتماسك المشيمة والثبكية، وبين صفة سمك اللحم وكل من صفات تماسك المشيمة و الثبكية, وبين صفتى تماسك المشيمة والثبكية. وبالنسبة للقسم الاخر من البحث والخاص بإنتاج وتقييم الهجن، فلقد سجلت معظم الهجن اعلى القيم، بالمقارنة بقيم الاباء فى كل الصفات تقريبا. وقدرت قوة الهجين بقيم معنوية وموجبة، على اساس متوسط الابوين او اعلى الاباء فى معظم الهجن المقيمة مما يشير الى اهمية الاستفاده من ظاهرة قوة الهجين فى النهوض ببعض الصفات الهامة فى الثمام. وبالنسبة لقيم درجة السيادة (potence ratio) فلقد لوحظ ظهور درجات متفاوته من السيادة (السيادة الكاملة والسيادة الفائقة والسيادة الجزئية) بالنسبة للصفات دهات المختلفة ، وبصورة عامة، فلقد أظهرت النتائج تفوق الهجن المقيمة على صنف المقارنة التجارى فى كل الصفات المدروسة . - المدان 
